DOI: 10.20472/BMC.2018.008.007

\title{
MÁRIA JANOŠKOVÁ
}

Technical university of Košice, Slovak Republic

\section{KATARÍNA ČULKOVÁ}

Technical university of Košice, Slovak Republic

\section{ADRIANA CSIKÓSOVÁ}

Technical university of Košice, Slovak Republic

\section{POSITION AND DEVELOPMENT OF SMALL AND MEDIUM ENTERPRISES IN EUROPEAN COUNTRIES}

\begin{abstract}
:
SMEs have irreplaceable task not only in macro-economic - in area of working posts creation, contribution to the flexibility of market mechanism or its contribution to the value added creation, but they are profitable also at the micro-economic level. The goal of the contribution is to search position and development of such enterprises in the frame of chosen European countries and how they contribute to economic growth and competitive environment. During the analysis we considered SME Policy Index. Overall position and development had been analyzed by chosen indexes, mainly index of economic freedom, global competition index, doing business index and corruption perception index. The results speak about increasing trend of SMEs in EU, creating employment possibilities, with limitation of barriers to make business in individual countries.
\end{abstract}

\section{Keywords:}

Business environment, Europe, Global markets, Post-communist countries, Small and medium enterprises.

JEL Classification: L26, M29 


\section{Introduction}

Small and medium enterprises (SMEs) are inseparable part of business environment in developed economies whole world. While in countries of Western Europe SMEs started to be important in 70-ties in 20th Century, in post-communist countries of middle and Eastern Europe the different was different. SMEs in this region had been rising in large numbers as a consequence of privatization and disintegration of big state companies, or through market liberalization with resulting to big number of new, mostly very small enterprises.

Dynamic growth of new risen companies depends not only on the volume and demand on the market, but also on the creation of positive conditions for the business, given by legislative frame. It means not only SMEs favoritism, but also creation of business environment that enables rapidly business subjects to develop and operate effectively.

SMEs have irreplaceable task not only in macro-economic - in area of working posts creation, contribution to the flexibility of market mechanism or its contribution to the value added creation, but they are profitable also at the micro-economic level. SMEs contribute to the flexible installment of new products at the market, to the production of specialized products or innovation growth, and by this way they make competition environment more strictly (Belanová, 2012).

The contribution follows up position and development of SMEs by monitoring of business environment through index of economic freedom, global competition index, doing business index, and corruption perception index. We resulted from hypothesis that SMEs in EU present the most abundant category of companies, therefore there is necessity to analyze SMEs area.

\section{Present state of problem solving}

Small and medium sized enterprises (SMEs) have a very important role as suppliers, distributors, customers, innovators or as a target of the corporate social responsibility for large enterprises (Van Tulder \& Da Rosa, 2014). Especially European firms are clearly amongst the leaders in experimenting with inclusive business strategies that include SMEs. However, their number still remains limited. Small and medium-sized enterprises (SMEs) play an important role as key engines for further economic growth and employment in the countries (SME policy index, 2012). But in many countries for many years SMEs played only a marginal role in the economy given the dominant position of large state-owned enterprises (Palaščáková, 2016). New business opportunities for SMEs are likely to arise with further progress being achieved in privatization and the establishment of functioning market economies and development of the SME sector has only recently become a priority for government policy as part of the country's efforts to diversify the economy and reduce dependence on the oil sector. Also OECD research shows that SMEs are an important driver of a country's competitiveness as they 
constitute a major source of knowledge, skills and innovation and contribute to employment generation and economic growth.

Position and functions of small and medium-size enterprises had been studied also by Kominkova (1989), stemmed from new conditions of international division of labor and necessity of assertion of innovation strategy as a condition of increasing competitiveness. The study outlines new views of traditional functions of these enterprises (in connection with specialization of production, employment and regional development policies, special attention to the role of a small innovating firm in scientific-technological development). Global opportunities for small and medium enterprises are given also by their position in the individual economic sector, which had been studied by some authors (Alonso et.al, 2016). This is important due to the emerging global markets and market requirements. On the other hand, it also provides the business opportunities in more mature markets, with a known or renewed interest.

Development of SMEs development in different countries and cultures studied Gibb (2000), considered the area is neglected in the researches. Since small and mediumsized enterprises (SMEs) react more quickly to various changes in the situation as well as being more resistant to sanctions and other external economic threats, focusing on their development is the most rational approach to the integrated socio-economic development of the concrete region (Krasulina, 2018).

There is therefore a strong case for greater academic interest. In the most advanced post-Communist countries of Europe, the dynamic growth of the small business sector has been the chief factor driving economic growth and has been accompanied by a number of public programs supporting Small and Medium-sized Enterprise (SME) development. Woodward (2001) argues that while the Visegrad countries are doing well on numbers of SMEs, they are lagging behind in the development of those firms. Also Sarovic et al. (2017) confirmed by the research there was an increase of the small and medium entrepreneurs' economic opportunities in post-communist countries and their material position and growth. Comparison with business experiences in countries joining the EU parallel with any country may provide lessons for managers of the companies to improve their competitive position. Such comparing made Balaton (2008), describing the strategies of SMEs located in Hungary parallel with joining the European Union and to evaluate the preparation of firms for the competitive conditions within the EU. Klochko and Issakova (1996) in comparison with other transition economies found that small business in Ukraine is rather poor and the small business sector does not fulfil the tasks that it should in the regeneration of a depressed economy.

\section{Methodology}

According European Commission recommendation we used classification, according which small enterprise is any company with less than 50 employees, with annual turnover to 7 mil. EUR or economic result the best 8 mil. EUR and at the same time it must be 
economically independent (Fetisová et al., 2014). Medium enterprise must be also economically independent, having less than 250 employees, with annual turnover the best 40 mil. EUR and economic results to 27 mil. EUR. In 2004 European Commission published recommendation No (2003/361/EC), with quantitative SMEs limitation according three criteria - turnover, balance sheet total and number of employees. This recommendation must be considered also in post-communist countries (Čulková et al., 2015) according following Table 1.

Tab. 1 SMEs limitation according EC recommendation No 2003/361/EC

\begin{tabular}{|l|c|c|c|}
\hline \multicolumn{1}{|c|}{ Category } & $\begin{array}{c}\text { Number of } \\
\text { employees }\end{array}$ & Annual turnover & $\begin{array}{c}\text { Balance sheet } \\
\text { total }\end{array}$ \\
\hline Micro enterprise & $<10$ & $<2$ mil. EUR & $<2$ mil. EUR \\
\hline Small enterprise & $<50$ & $<10$ mil. EUR & $<10$ mil. EUR \\
\hline Medium enterprise & $<250$ & $<50$ mil. EUR & $<43$ mil. EUR \\
\hline
\end{tabular}

Source: EC recommendation No 2003/361/EC

EU member states do not have obligation to apply this definition, but European Commission encourages member states together with European investment bank and European investment fund to it application as much as possible with aim to simplify classification at various types of grants. Majority of government institutions in EU countries is therefore applying the definition. The data had been used also from Tan and Haji (2017), providing big data of SMEs, referring to the massive amount of data generated from IT systems.

During the analysis we considered also the SME Policy Index. Due to its calculation Eastern Partner Countries 2012 (Enterprise Policy Performance Assessment) has been jointly developed by OECD, the European Commission, the European Training Foundation (ETF) and the European Bank for Reconstruction and Development (EBRD) in collaboration with representatives from the Eastern Partner countries. It builds on the experience of the Western Balkans and the Euro-Med region, it also serves as a tool for policy makers to design and implement comprehensive tools and mechanisms to support SME growth and employment generation (SME policy index, 2012).

\subsection{Evaluation of SMEs business environment}

Creation of proper business environment is one of the basic assumptions for growth of the economy, employment and competition not only at the national, but also at the regional level. By this way business environment influences immediately standard of living and quality of life in the region. State of business environment in the individual countries is regularly monitored. Monitoring of business environment is presently done by number of organizations. Through indexes constructed according various quantitative and qualitative criteria they make ranking of the countries with the best business environment. 
From the most important world indexes, orientated to the evaluation of business environment we considered during the analysis following indexes:

Index of economic freedom (IEF) - orientated to the economic openness of the country, effectiveness of regulation, applying of legislation and competitiveness. Heritage Foundation constructs the index annually in cooperation with Wall Street Journal. Resulting score of the index is $0-100$. In 2017180 countries had been ranked to the IEF index. The higher value the country achieves, the more economically free the country is.

Global competition index $(\mathrm{GCl})$ - orientated to the evaluation of economic growth sustainability in middle term horizon. $\mathrm{GCl}$ index evaluates business environment according components, grouped to 12 pillars of competitiveness - infrastructure, public finances, macro-economic stability, basic education and health of inhabitants, higher education and training, job market and good market effectiveness, technological preparation, financial market maturity, volume of the market, business processes maturity and level of innovation. Resulting value of the index presents weighted arithmetic mean from 12 mentioned pillars. Value of the index is 1-7 (the best evaluation), constructed by World Economic Forum and in 2017 - 137 countries had been considered during the index calculation.

Doing Business index (DB) - complex index, regarding 10 criteria - beginning of the business, acquisition of access to energy and building permission, property evidence, acquiring of credits, way of taxes collection, investors protection, cross-border trade, observance of agreements among business partners and insolvency solving. Index is evaluated and published annually by World Bank. In 2017 - 190 countries had been included to the index.

Corruption perception index (CPI) - summary index, combined various sources, connected the corruption in the individual countries. But because of the corruption is heavily quantified, CPI results during the evaluation from the researches of public opinion, made by independent reputable institutions. Index value is $0-10$. The higher is index value; the lower is level of corruption. Transparency International evaluates and published the index since 1995.

\section{$4 \quad$ Results}

According Muller et al. (2017) SMEs in EU present the most abundant category of companies. Micro enterprises present yet $93.0 \%$, small enterprises $5.8 \%$ and medium enterprises $0.9 \%$. Structure of SMEs in the frame of EU 28 according volume criteria in 2016 is illustrated by following Figure 1. 


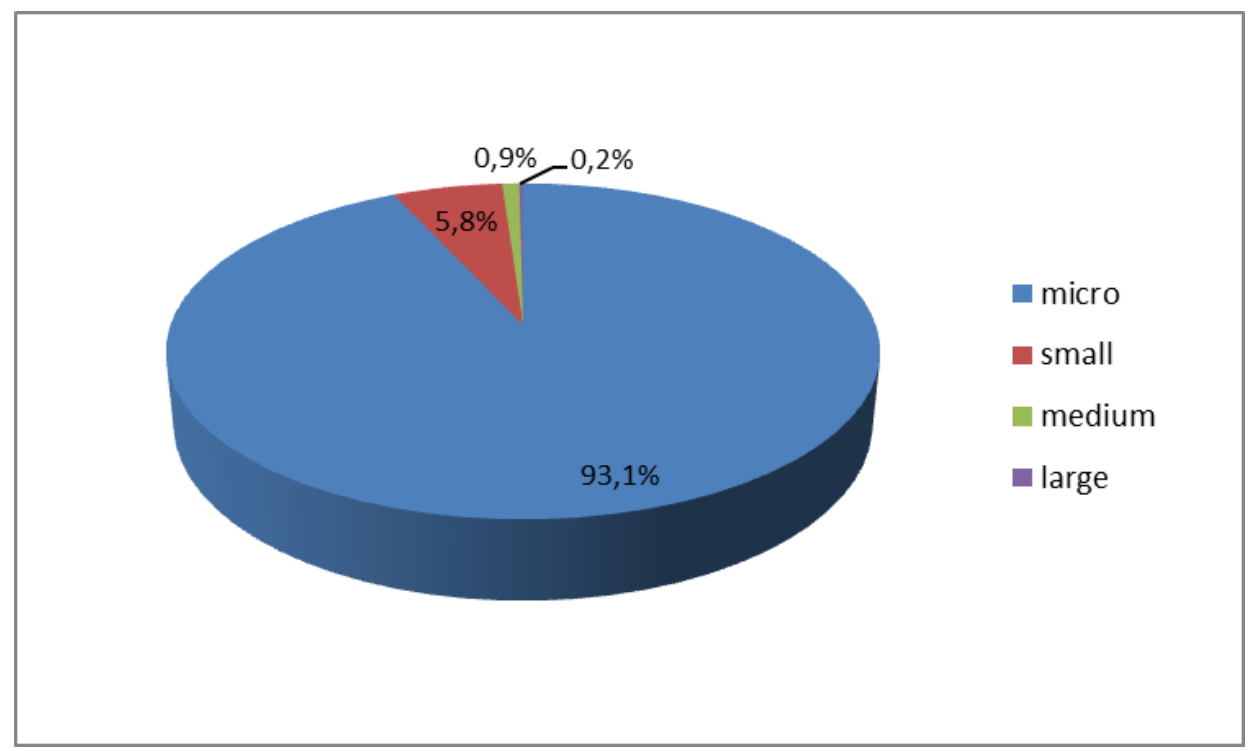

Figure 1: SMEs structure according volume criteria in 2016 in EU 28

Source: own processing according European Commission

SMEs development in EU has increasing trend from 2012. During 2012-2016 there is recorded increasing number of SMEs, from the view of micro enterprises, as well as small and medium enterprises. But at the SMEs development evaluation there is necessary to mention that increase in 2013 had been partially caused by Croatia acceptance to EU member state. According the study of European Commission 24 million SMEs operated in 2016 in EU 28 non-financial sector, which presents $99.8 \%$ from total number of business subjects.

SMEs employed more than 93 million people $(66.6 \%)$ and created more than 4 trillion EUR of value added $(56.8 \%)$. Mostly micro enterprises contributed to the employment in EU 28 in 2016 - employed $29.8 \%$ working power. Small enterprises employed $20 \%$ and medium enterprises employed $16.7 \%$ from total number of employees in non-financial sector. Rate of micro enterprises on value added presented $20.9 \%$, small enterprises $17.8 \%$ and medium enterprises $18.2 \%$. Rate of individual SMEs categories on employment and value added in EU 28 in non-financial sectors is given by Figure 2. (Lukáč et al., 2017). 

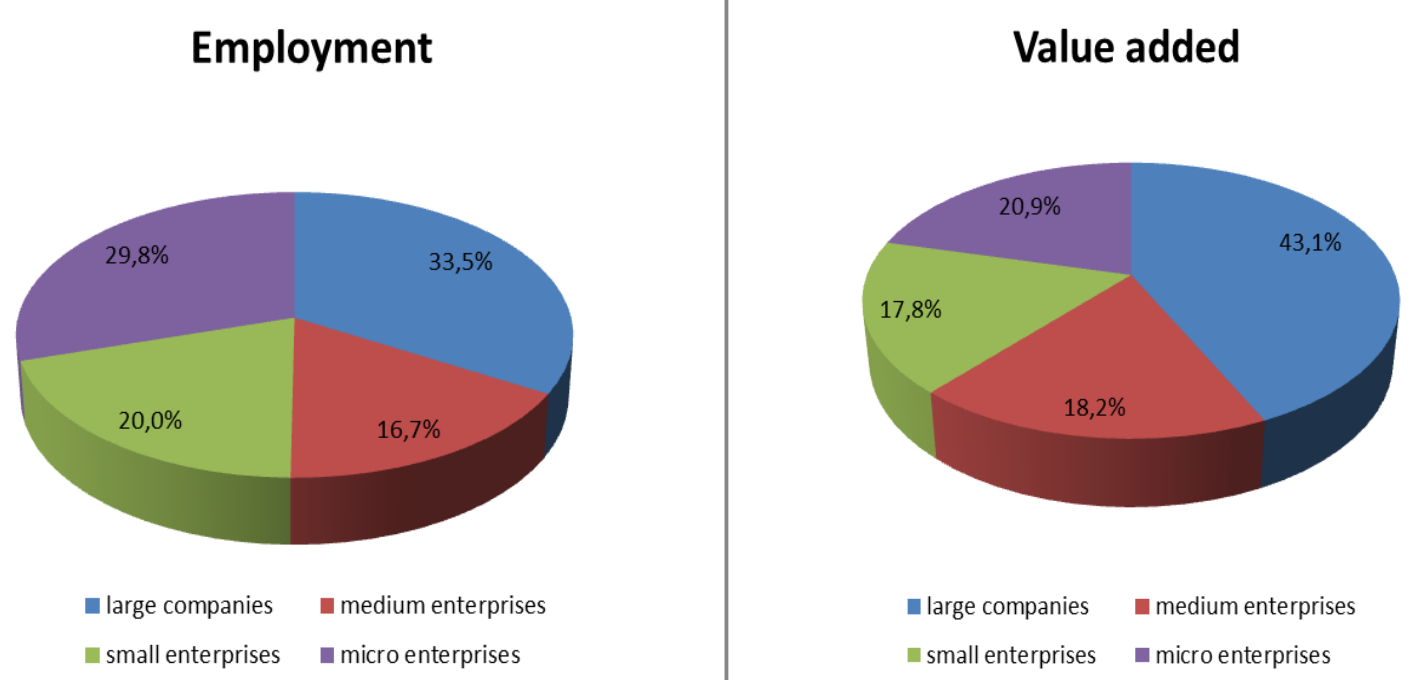

Figure 2: Rate of individual SMEs categories on employment and value added in EU 28 in 2016 in non-financial sector

Source: own processing according European Commission

In EU28 SMEs created the most working posts in Greece (86.9\%), Cyprus (83.0\%) and Malta (79.3\%). On the other hand, the least employees had been employed in United Kingdom (53.5\%), France (63.2\%) and Germany (63.4\%). Among V4 countries the most working posts presented SMEs in Slovakia (72.1\%) and the least in Czech Republic (66.8\%). Review of SMEs rate on employment in individual EU countries is given by Figure 3.

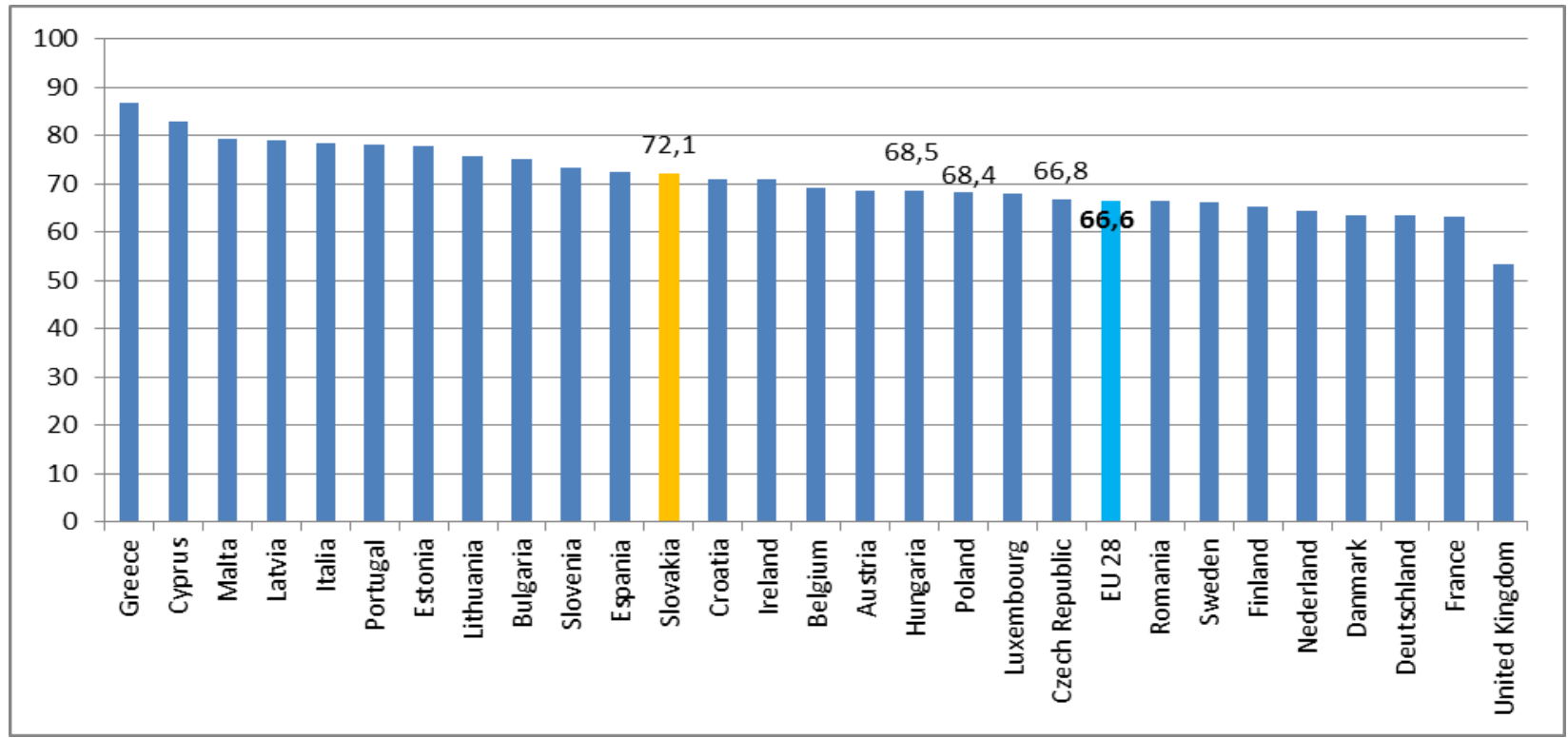

Figure 3: SMEs rate on employment according EC in 2016 in EU countries

Source: own processing according EC data 
According European Commission on the value added creation participated mostly SMEs, operating at Malta $(82.0 \%)$, Estonia $(75.7 \%)$ and Greece $(73.2 \%)$. The least contribution of SMEs on value added was recorded in Ireland (36.6\%), Great Britain $(51.8 \%)$ and Poland $(52.5 \%)$. In the midst of V4 countries the highest contribution of SMEs on value added was in Czech Republic (54.5\%), followed up by Slovakia (54.4\%). Figure 4 illustrates review of SMEs rate on value added in individual EU countries.

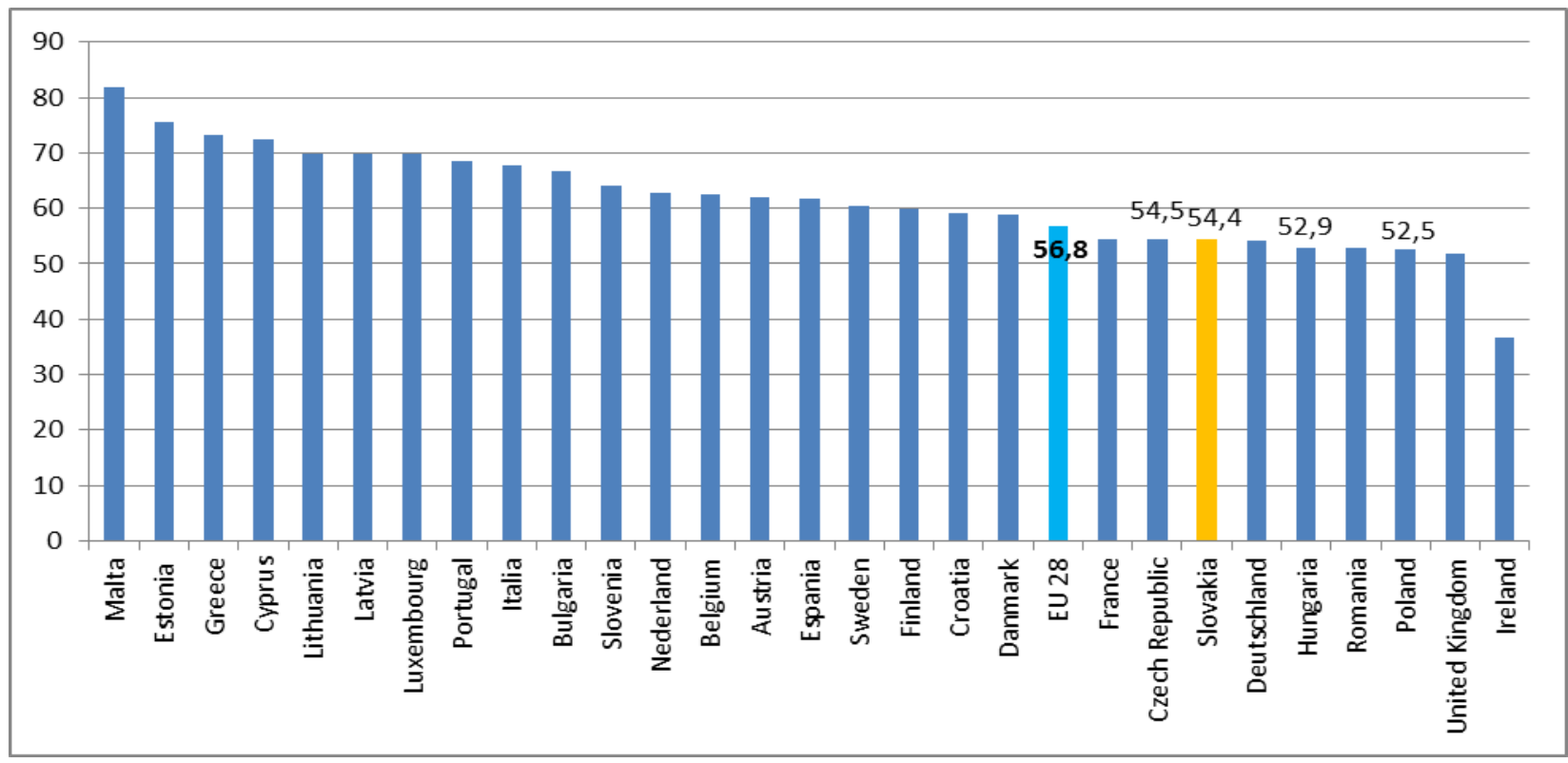

Figure 4: SMEs rate on value added according EC in 2016 in EU countries Source: own processing according EC data

European Commission in cooperation with European Central Bank makes from 2013 annual research of business environment, orientated to the analysis of most often problems in SMEs development. According limitation of most often problems respondents select barriers according the weights. Barriers with the highest weight of the influence are then indicated as most problematic.

According the newest research, realized in 2016 small and medium businessmen from EU28 consider the biggest problem as purchasing demand. Yet $25 \%$ respondents have a problem to find consumers - mostly enterprises, acting in Austria, indicated this possibility. According $20 \%$ of respondents, second biggest barrier means lack of qualified workers. Number of SMEs meets this problem - mostly in Belgium, Croatia, Finland, France, Latvia, Luxemburg, Netherland, Poland, Slovakia and Great Britain. Third barrier that SMEs encounter mostly is competition, which is negatively perceived mainly in Latvia and Malta. Only 9\% SMEs indicated as most serious problem for their development as access to financial sources (see Figure 5). Not sufficient access to finances is perceived mostly by businessmen from Cyprus and Greece. 


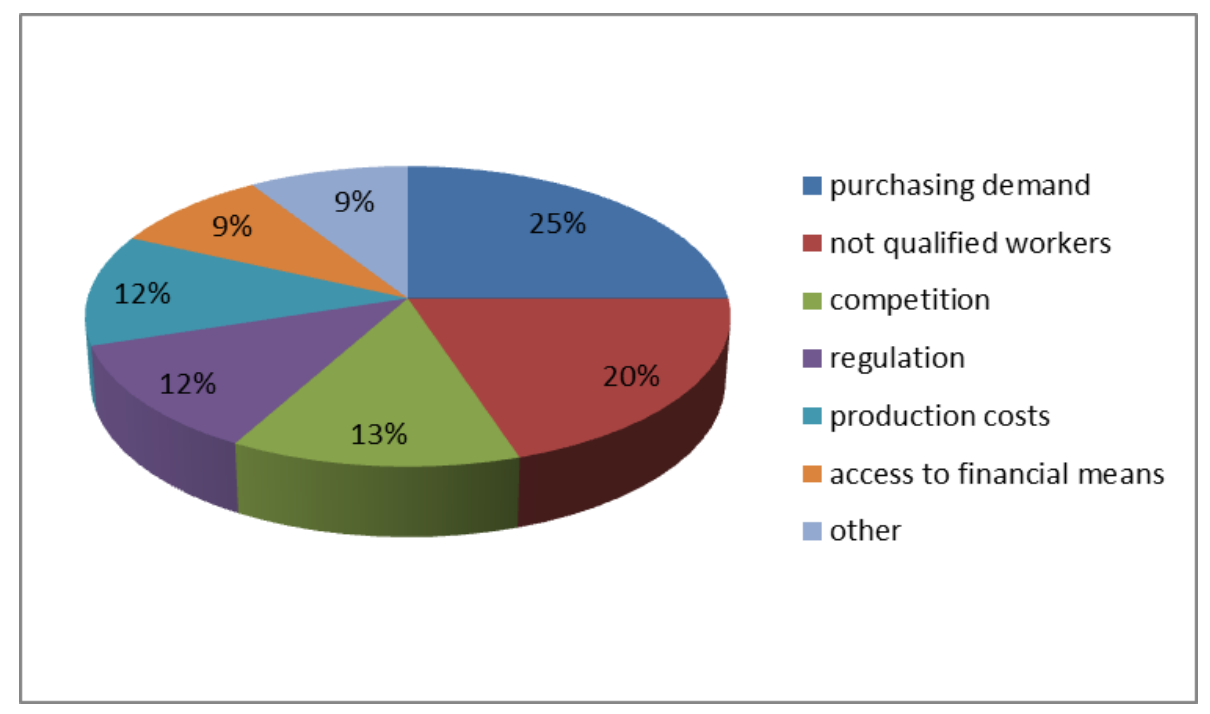

Figure 5: Main barriers for SMEs business in EU28 in 2016

Source: own processing according EC data

Following Table 2 mention 10 countries with the best business environment according quantitative and qualitative criteria of individual world indexes - GCI, IEF, DB a CPI. In the frame of EU countries, we regarded during the evaluation also values of indexes especially in V4 countries.

Table 2: Countries with the best business environment according IEF, GCI, DB and CPI in 2016 / 2017

\begin{tabular}{|c|c|c|c|c|c|c|c|}
\hline \multicolumn{2}{|r|}{ IEF } & \multicolumn{2}{|r|}{$\mathbf{G C l}$} & \multicolumn{2}{|r|}{ DB } & \multicolumn{2}{|r|}{ CPI } \\
\hline & Country & & Country & & Country & & Country \\
\hline 1. & Hong Kong & 1. & Switzerland & 1. & New Zeeland & 1. & Denmark \\
\hline 2. & Singapore & 2. & USA & 2. & Singapore & 1. & New Zeeland \\
\hline 3. & New Zeeland & 3. & Singapore & 3. & Denmark & 3. & Finland \\
\hline 4. & Switzerland & 4. & Netherland & 4. & Korea & 4. & Sweden \\
\hline 5. & Austria & 5. & Germany & 5. & Hong Kong & 5. & Switzerland \\
\hline 6. & Estonia & 6. & Hong Kong & 6. & USA & 6. & Norway \\
\hline 7. & Canada & 7. & Sweden & 7. & Great Britain & 7. & Singapore \\
\hline 8. & SAE & 8. & Great Britain & 8. & Norway & 8. & Netherland \\
\hline 9. & Ireland & 9. & Japan & 9. & Georgian & 9. & Canada \\
\hline 10. & Chile & 10. & Finland & 10. & Sweden & 10. & Germany \\
\hline & & & $\ldots$ & & ... & & $\ldots$ \\
\hline 28. & $\begin{array}{l}\text { Czech } \\
\text { Republic }\end{array}$ & 31. & $\begin{array}{l}\text { Czech } \\
\text { Republic }\end{array}$ & 27. & Poland & 29. & Poland \\
\hline 45. & Poland & 39. & Poland & 30. & Czech Republic & 47. & Czech Republic \\
\hline 56. & Hungary & 59. & Slovakia & 39. & Slovakia & 54. & Slovakia \\
\hline 57. & Slovakia & 60. & Hungary & 48. & Hungary & 57. & Hungary \\
\hline
\end{tabular}

Source: own processing according data Heritage Foundation, World Economic Forum, World Bank and Transparency International 
In conditions of Slovakia there is used also index of Business Alliance of Slovakia, with title "Superindex PAS", which evaluates and compares business environment of Slovakia with other world countries. The index combines results of 4 world indexes, to which the weights are given. It evaluates data from GCl (weight 30\%), IEF (weight $30 \%$ ), Doing Business (weight 30\%) and ICP (weight 10\%). Reference value of Superindex PAS is 100 points - expressing average score of five countries with the best business environment. Presently it is considered as most complex index, evaluating development of business environment in Slovakia. Table 3 expresses ranking of countries with the best business environment according Superindex PAS in 2017, including V4 countries.

Table 3: Superindex PAS 2017

\begin{tabular}{|c|l|c|c|c|}
\hline & \multicolumn{1}{|c|}{ Country } & \multirow{2}{*}{ Score } & \multicolumn{2}{c|}{ Change } \\
\cline { 4 - 5 } & & & Position & Score \\
\hline 1. & Singapore & 103.1 & $=$ & -0.65 \\
\hline 2. & Hong Kong & 101.1 & $=$ & +0.94 \\
\hline 3. & New Zeeland & 100.1 & $=$ & +1.29 \\
\hline 4. & Switzerland & 98.2 & $=$ & +0.27 \\
\hline 5. & Sweden & 96.3 & $\uparrow 5$ & +1.43 \\
\hline 6. & Denmark & 96.3 & $\downarrow 1$ & - \\
\hline 7. & Great Britain & 96.2 & $=.30$ \\
\hline 8. & USA & 96.1 & $\downarrow 2$ & +0.41 \\
\hline 9. & Norway & 95.2 & $\uparrow 4$ & +1.22 \\
\hline 10. & Finland & 95.0 & $\downarrow 2$ & - \\
\hline & & \multicolumn{3}{|c|}{0.10} \\
\hline 30. & Czech Republic & 81.1 & $\downarrow 1$ & +0.84 \\
\hline 33. & Poland & 80.7 & $\downarrow 3$ & +0.74 \\
\hline 38. & Slovakia & 76.6 & $\downarrow 3$ & +0.12 \\
\hline 51. & Hungary & 76.5 & $\downarrow 7$ & - \\
\hline
\end{tabular}

Source: own processing according Business Alliance Slovakia

According Superindex PAS 2017 Singapore is country with the most positive business environment. Second and third place belong to Hong Kong and New Zeeland. In Europe the best place belongs to Switzerland $-4^{\text {th }}$ positions, followed by Sweden and Denmark. Comparing with previous year Sweden improved the position, moving by 5 ranks and Norway, which occupied $9^{\text {th }}$ place. Great Britain maintained the $7^{\text {th }}$ position. On the other hand, USA and Finland worsened the position by two positions. In comparing with previous year Slovakia worsened by $3^{\text {th }}$ positions and in 2017 stayed at $38^{\text {th }}$ position. Index value in Slovakia increased only slightly - by $0.12 \%$ to $76.6 \%$. From V4 countries according the index Czech Republic has the best business environment, occupying $30^{\text {th }}$ position with value $81.1 \%$. The worst position in EU belongs to Hungary, Croatia and Greece. 


\section{Discussion}

Government support in promoting SME development is necessary to find an appropriate response to address these challenges. This area has been studied by some research, for example Smallbone et al. (2001) studied role of the government in the process of SMEs development, especially in transition economies. Effective institutional structures and consultation mechanisms can help to overcome these constraints as small enterprises otherwise do not have the ability to influence nation-wide policies. By this way SMEs would benefit from improved policy frameworks based on a coherent set of SME policies that foster entrepreneurship and competitiveness (SME policy index, 2012). Some SMEs have developed despite the actions of governments, although the number of private enterprises per capita remains small and their qualitative characteristics often reflect the difficult operating conditions. But something crucial is generally missing from these programs; namely, an attempt to go beyond the problems of individual businesses to approaches based on forms of association and cooperation which preserve, and even enhance, the overall competitiveness of the economy (Woodward, 2001).

As a result, their contribution to economic and social change is less than it could be, mainly due to an unstable environment and an institutional context that has yet to establish the framework conditions for sustainable private sector development. It means that reform of the distorted legal and financial infrastructures that exist in these countries is the highest priority need (Smallbone et al., 2001). Moreover, the difference in the degree of small business development in different regions of the country gives rise to the idea that emphasis on small business support at the local level would significantly improve the situation (Kloschko \& Issakova, 1996).

\section{Conclusion}

Creation of proper business environment is one of the basic assumptions for growth of the economy, employment and competition not only at the national, but also at the regional level. SMEs are attempting to overcome their problems of individual businesses, and their success can contribute to competitiveness of the economy. Presented paper shows that SMEs have their contribution to economic and social area, but the situation of SMEs business can be still improved, since it is less than it could be. Also results show that their contribution to economic and social change is less than it could be, mainly due to an unstable environment and an institutional context that has yet to establish the framework conditions for sustainable development. Therefore, state of business environment in the individual countries must be regularly monitored. Presented analysis has some limitations, mainly index of economic freedom is very complex and therefore there are some problems with its calculation. Further research could be orientated to volume of demand on market and legislative frame of business, since dynamic growth of new risen companies depends on positive conditions for the business, given by legislative 
frame. Government support in promoting SME development is necessary to find an appropriate response to address these challenges.

\section{Acknowledgement}

Contribution is part of the project VEGA No. 1/0310/16 - Identification of Factors Determining Bankruptcy of Companies in Conditions of Chosen Industrial Sectors, and project VEGA No. 1/0651/18 - Research of institutional environment influence to the corporate social responsibility, consumer's satisfaction and performance of the company and project KEGA No. 031TUKE-4/2016.

\section{References}

Alonso, A., Coosemans, T., Perlo, P., Comoglio, M., Otella, M., Reeves, C., Bierau, F., Mueller, B., Meyer, G., Koehler, U., Feyder, C., Gallego, I., Chefneux, M., Zegers, P., \& Deix, S. 2016. GO4SEM recommendations to support innovation links for entering global e-mobility markets. Transportation Research Procedia, 14(2016), 3667-3675. DOI: 10.1016/j.trpro.2016.05.440.

Balaton, K. 2008. Enterprise strategies in Hungary in the period of joining the European Union. Competitiveness Review, 18(1-2), 9-19. DOI: 10.1108/ 10595420810874574.

Belanová, K. 2012. Approach to financial sources as key bareer for SMEs development. SMEs life cycle and their financial needs (in slovak). Biatec, 4(2012), 28-30.

Čulková, K., Csikósová, A., \& Janošková, M. 2015. Development of established and cancelled companies in Slovakia. Journal of Applied Economics Sciences, 10(5), 644-653.

Fetisovová, E., Nagy, L., \& Vlachynský, K. 2014. Actual trends in SMEs business (in slovak). Bratislava: Ekonóm.

Gibb, A. 2000. Small and medium enterprise development: borrowing from elsewhere? A research and development agenda. Journal of Small Business and Enterprise Development, 7(3), 199-211.

Hrehová, D., \& Žiaran, P. 2015. Stimulating the entrepreneurial spirit and training of students for the needs of the labor market. Proceedings of Conference on Current Problems of the Corporate Sector, 208218.

Kominkova, Z. 1989. The role of small and medium-size enterprises in economic development of West European countries. Ekonomicky casopis, 37(8), 695-713.

Kloschko, Y., \& Issakova, N. 1996. Small business sector in Ukrainian transition economy: Achievements to date. Entrepreneurship and Regional Development, 8(2), 127-140. DOI: $10.1080 / 08985629600000008$.

Krasulina, O. Y. 2018. Problems of enterpreneurship development in the Russian Arctic Zone. IOP conference series: Earth and Environmental Science, 180(1), 1-7. Doi: 10.1088/1755$1315 / 180 / 1 / 012019$.

Lukáč, J., Lukáč, J., \& Rozkošová, A. 2017. Financial and economic performance in context of SMEs (in slovak). Košice: TypoPress.

Muller, P. et al. 2017. Annual report on European SMEs 2016/2017. Focus on self-employment. London: Economics Innova. [online] https://ec.europa.eu/docsroom/ documents/26563/attachments/1/translations/en/renditions/native. 
Palaščáková, D. 2016. Analysis of shadow economy in Slovakia: Comparison to other EU countries. Actual Problems of Economics, 178(4), 63-68.

Sarovic, R., Ceranic, G., \& Samardzic, O. 2017. The material position of entrepreneurs in Montenegro in self-assessments. Sotsiologicheskie Issledovaniya, 4(2017), 116-121.

Smallbone, D., Welter, F., Isakova, N., \& Slonimski, A. 2001. The contribution of small and medium enterprises to economic development in Ukraine and Belarus: Some policy perspectives. Most, 11(3), 253-273. DOI: 10.1023/A:1013113312503.

SME Policy Index: Eastern Partner Countries 2012: Progress in the Implementation of the Small Business Act for Europe, ume 978-92-64178847, 2012, Pages 1-313.

Tan, C., \& Haji, M. 2017. Big data education portal for small and medium sized enterprises (SMEs). ACM International Conference Proceeding, series 20, 11-15.

Van Tulder, R., \& Da Rosa, A. 2014. Multinationals and small and medium sized enterprises (SMEs): A linkages perspective on inclusive development strategies. Progress in International Business Research, 8, 203-227. DOI: 10.1108/S1745-8862(2013)0000008014

Woodward, R. 2001. SME support in post-communist countries: Moving from individual to cooperative approaches (reflections on the Polish case). Most, 11(3), 275-294. DOI: 10.1023/A:1013117413412 